$\begin{array}{r}\text { Phinisi Integration Review } \\ \text { Vol. 2, No.1, Februari 2019 Hal 039-046 } \\ \text { Website: } \underline{\text { http://ojs.unm.ac.id/pir }} \\ \text { p-ISSN: 2614-2325 dan e-ISSN: 2614-2317 } \\ \hline\end{array}$

\title{
Perbandingan Hasil Belajar Siswa Kelas X Mata Pelajaran Ekonomi Menggunakan Model Inkuiri Terbimbing Dengan Ingkuiri Bebas di SMA Negeri 1 Liliriaja Kabupaten Soppeng
}

\author{
Musdalifah $^{(1),}$ Sulfaidah ${ }^{(2)}$ \\ STKIP Pembangunan Indonesia \\ email: musdalifahSTKIP@gmail.com
}

\begin{abstract}
Abstrak. Model pembelajaran yang dipandang mampu mengembangkan hasil belajar dan pemahaman konsep siswa yaitu model pembelajaran inkuiri. Rumusan masalah dalam penelitian ini adalah (1) hasil belajar ekonomi siswa Kelas X di SMA Negeri 1 Liliriaja Kabupaten Soppeng melalui model pembelajaran inkuiri terbimbing, (2) hasil belajar ekonomi siswa Kelas X Di SMA Negeri 1 Liliriaja Kabupaten Soppeng melalui model pembelajaran inkuiri bebas, (3) perbedaan hasil belajar siswa antara kelompok siswa yang belajar dengan model pembelajaran inkuri terbimbing dengan kelompok siswa yang belajar dengan menggunakan model pembelajaran inkuiri bebas Kelas X di SMA Negeri 1 Liliriaja Kabupaten Soppeng. Penelitian ini merupakan jenis penelitian quasi experiment dengan desain penelitian non-equivalent control group design. Populasi penelitian ini adalah seluruh siswa kelas XA dan XB di SMA Negeri 1 Liliriaja Kabupaten Soppeng yang berjumlah 60 orang. Teknik pengambilan sampel menggunakan teknik sampling jenuh. Teknik analisis data yang digunakan adalah analisis statistic deskriptif dan analisis statistik inferensial. Uji homogenitas data diperoleh nilai sig sebesar 0,824 pada data hasil pre test, berarti nilai sig lebih besar dari nilai $\alpha=0,05$ $(0,824>0,05)$. Dengan demikian H0 di terima. Begitupula nilai sig sebesar 0,336 pada data hasil post test, berarti nilai sig lebih besar dari nilai $\alpha=0,05(0,336>0,05)$. Dengan demikian $\mathrm{HO}$ di terima. Maka dapat disimpulkan bahwa data hasil pre-test dan post test pada kelas inkuiri terbimbing dan inkuiri bebas bersifat homogeny.
\end{abstract}

Kata Kunci: Hasil Belajar Siswa; Model Inkuiri Terbimbing; Inkuiri Bebas

\begin{abstract}
Inquiry learning method is one of the learning methods that can develop students' learning outcome and understanding concept. Problem statements in this study emphasize on (1) the students' learning outcome on Economics subject of class $\mathrm{X}$ at SMA Negeri 1 Liliriaja, Soppeng District through guided inquiry learning method, (2) the students' learning outcome on Economics subject of class X at SMA Negeri 1 Liliriaja, Soppeng District through open inquiry learning method, (3) the differences in students' learning outcome between a group of students who studies with guided inquiry learning method and a group of students who studies with open inquiry learning method of class X at SMA Negeri 1 Liliriaja, Soppeng District. This research used a type of quasi experiment research with non-equivalent control group design. In addition, the population of this study was all students of class XA and XB at SMA Negeri 1 Liliriaja, Soppeng District consisting of 60 people. The sampling technique used in this study was saturation sampling while the data analysis technique was descriptive and inferential statistics. The data homogeneity test shows sig value of 0.824 on the pre-test, meaning that the sig value is greater than the value of $\alpha=0.05(0.824>0.05)$ and $\mathrm{H} 0$ is accepted. The sig value of
\end{abstract}


was 0.336 on the post-test. It means that the sig value is greater than the value of $\alpha=0.05$ $(0.336>0.05)$ and $\mathrm{H} 0$ is accepted. The researcher, then, concludes that the data from the pre-test and post-test on guided inquiry class and open inquiry data is homogeneous.

Keywords: Student Learning Outcome; Guided Inquiry; Open Inquiry Learning Method

Ini adalah artikel dengan akses terbuka dibawah licenci CC BY-NC-4.0 (https://creativecommons.org/licenses/by-nc/4.0/).

\section{PENDAHULUAN}

Pendidikan merupakan salah satu komponen yang ikut menunjang keberhasilan pembangunan bangsa. Semakin tinggi tingkat pendidikan masyarakat, kualitas kehidupan bangsa juga meningkat. Selain itu pendidikan juga tidak lepas dari proses pembelajaran. Dalam Peraturan Pemerintah No 19, ayat (1) dinyatakan bahwa "proses pembelajaran pada satuan pendidikan diselenggarakan secara interaktif, inspiratif, menyenangkan, menantang, memotivasi siswa untuk berpartisipasi aktif, memberikan ruang gerak yang cukup bagi prakarsa, kreativitas dan kemandirian sesuai dengan bakat, minat dan perkembangan fisik serta psikologi siswa".

Sementara itu, pembelajaran Ekonomi di SMA Negeri 1 Liliriaja masih banyak yang menggunakan pembelajaran langsung yang didominasi oleh guru dengan ceramah serta cenderung memposisikan siswa sebagai pendengar dan pencatat yang menyebabkan siswa kurang menjadi aktif dan cenderung menjadi pasif dalam pembelajaran sehingga akan berdampak pada hasil belajar siswa dan terhadap keterampilan proses sains siswa. Hal ini sangat tidak sesuai dengan pembelajaran ekonomi karena di dalam pembelajaran ekonomi siswa dituntut untuk aktif. Sehubungan dengan hal tersebut, sudah saatnya guru melakukan inovasi dalam pembelajaran ekonomi guna meningkatkan prestasi kearah yang maksimal dan memberikan ruang untuk meningkatkan minat siswa dalam belajar. Perbaikan dalam pembelajaran dapat dilakukan dengan mengadakan perubahan/perbaikan model pembelajaran yang berorientasi pada aktivitas siswa. Inovasi yang dapat dilakukan dengan menggunakan variasi model pembelajaran yang memberikan kesempatan siswa untuk aktif dalam proses pembelajaran.
Model pembelajaran yang dipandang mampu mengembangkan hasil belajar dan pemahaman konsep siswa yaitu model pembelajaran inkuiri. Model pembelajaran inkuiri menurut Colburn (dalam Suarnithi, 2012) tidak hanya mendikte tentang konsep, tetapi mendorong pengalaman belajar siswa untuk memahami konsep-konsep ilmiah, yang dapat memberikan pemahaman yang lebih mendalam, membuat konsep lebih lama diingat dan bermakna bagi siswa.

Pada model pembelajaran inkuiri terbimbing siswa diberikan motivasi di dalam belajar dan guru masih banyak berperan di dalam pembelajaran, sedangkan pada model pembelajaran inkuiri bebas guru tidak memberikan motivasi atau peran guru sangat sedikit dan siswa diberikan kebebasan di dalam memecahkan masalah. Sehingga peneliti tertarik melakukan penelitian eksperimen dengan melakukan perbandingan penerapan model pembelajaran inkuiri terbimbing dengan model pembelajaran inkuiri bebas yang akan diterapkan pada siswa kelas X di SMA Negeri 1 Liliriaja Kabupaten Soppeng.

\section{Inkuiri Terbimbing(Guided Inquiry} Approach)

Menurut Suparno, inkuiri terbimbing adalah inkuiri yang banyak dicampuri oleh guru. Guru banyak mengarahkan dan memberikan petunjuk baik lewat prosedur yang lengkap dan pertanyaan-pertanyaan pengarahan selama proses inkuiri (Ristanto 2010). Model pembelajaran yang dapat melibatkan keaktifan siswa adalah model penemuan (discovery) atau penyelidikan (inquiry).

Model yang digunakan pada penelitian ini adalah modelinkuiri terbimbing (Guide Inquiry). Inkuiri yang dalam bahasa inggris "inquiry" mempunyai arti pertanyaan, pemeriksaan, atau penyelidikan. Model Guided Inquiry berarti 
suatu kegiatan belajar yang melibatkan seluruh kemampuan siswa untuk mencari dan menyelidiki suatu permasalahan secara sistematis, logis, analitis, sehingga dengan bimbingan dari guru siswa dapat merumuskan sendiri penemuannya dengan penuh percaya diri.

\section{Inkuiri Bebas (Free Inquiry Approach)}

Model pembelajaran inkuiri bebas menempatkan siswa seolah-olah bekerja seperti seorang ilmuwan. Siswa diberi kebebasan menentukan permasalahan untuk diselidiki, menemukan dan menyelesaikan masalah secara mandiri, merancang prosedur atau langkahlangkah yang diperlukan. Menurut Gulo, strategi inkuiri berarti suatu rangkaian kegiatan belajar yang melibatkan secara maksimal seluruh kemampuan siswa untuk mencari dan menyelidiki secara sistematis, kritis, logis, analitis sehingga siswa dapat merumuskan sendiri penemuannya dengan penuh percaya diri. (Trianto, Mendesain Model Pembelajaran Inovatif-Progresif 2010).

Belajar dengan model ini mempunyai beberapa kelemahan, antara lain: 1) waktu yang diperlukan untuk menemukan sesuatu relatif lama sehingga melebihi waktu yang sudah ditetapkan dalam kurikulum, 2) karena diberi kebebasan untuk menentukan sendiri permasalahan yang diselidiki, ada kemungkinan topik yang diplih oleh siswa di luar konteks yang ada dalam kurikulum, 3) ada kemungkinan setiap kelompok atau individual mempunyai topik berbeda, sehingga guru akan membutuhkan waktu yang lama untuk memeriksa hasil yang diperoleh siswa, 4) karena topik yang diselidiki antara kelompok atau individual berbeda, ada kemungkinan kelompok atau individual lainnya kurang memahami topik yang diselidiki oleh kelompok atau individual tertentu, sehingga diskusi tidak berjalan sebagaimana yang diharapkan.

\section{Hasil Belajar}

Hasil belajar adalah perubahan tingkah laku sebagai hasil belajar dalam pengettian yang lebih luas mencakup bidang kognitif, afektif, dan psikomotorik (Sudjana 2009). Hasil belajar merupakan hasil dari suatu interaksi tindak belajar dan tindak mengajar. Dari sisi guru, tindak mengajar diakhiri dengan proses evaluasi hasil belajar. Dari sisi siswa, hasil belajar merupakan berakhirnya penggal dan puncak proses belajar. (Dimyati and Mudjiono 2013).

Hasil belajar yang dicapai siswa dipengaruhi oleh dua faktor yakni faktor dari dalam diri siswa dan faktor dari luar diri siswa. Dari pendapat ini faktor yang dimaksud adalah faktor dalam diri siswa perubahan kemampuan yang dimilikinya seperti yang dikemukakan oleh Clark menyatakan bahwa hasil belajar siswadisekolah $70 \quad \%$ dipengaruhi oleh kemampuan siswa dan $30 \%$ dipengaruhi oleh lingkungan.

\section{METODE PENELITIAN}

\section{Populasi dan Sampel}

Populasi penelitian ini adalah seluruh siswa kelas X di SMA Negeri 1 Liliriaja Kabupaten Soppeng tahun ajaran 2017-2018 yang terdiri dari 2 kelas yaitu Kelas X.A dan Kelas X.B. Penelitian ini menggunakan sampel jenuh yaitu populasi dalam penelitian ini sekaligus sampel penelitian.(Arikunto 2013). Sampel yang dimaksud adalah seluruh siswa kelas X di SMA Negeri 1 Liliriaja Kabupaten soppeng tahun ajaran 2017-2018yang terdiri dari 2 kelas, yaitu kelas X.A yang terdiri dari 30 orang siswa sampai kelas X.B yang terdiri dari 30 orang siswa.

\section{Teknik Analisis Data}

a. Uji Validitas dan Reliabilitas

1) Validitas Butir Soal

Suatu butir soal dikatakan valid apabila memiliki dukungan yang besar terhadap skor total.Dengan kata lain, sebuah item tes memiliki validitas tinggi jika skor pada item itu mempunyai kesejajaran dengan skor total.Kesejajaran ini dapat diartikan sebagai korelasi, sehingga untuk mengetahui validitas item ini digunakan rumus korelasi Product Moment Pearson. Dalam penelitian ini, butir tes dikatakan valid jika mempunyai validitas cukup, tinggi, atau sangat tinggi, sedangkan untuk butir-butir tes yang memiliki validitas rendah dan sangat rendah dikategorikan tidak valid dan dikeluarkan.

2) Reliabilitas Soal

Reliabilitas instrumen tes dihitung untuk mengetahui konsistensi hasil tes. Untuk menghitung reliabilitas perangkat tes ini digunakan rumus yang sesuai dengan bentuk tes uraian (essay), 
b. Analisis Statistik Deskriptif

Analisis statistik deskriptif digunakan untuk mendeskripsikan hasil belajar ekonomi yang diperoleh siswa baik pada kelompok kontrol maupun kelompok eksperimen. Guna mendapatkan gambaran yang jelas tentang hasil belajar ekonomi siswa, maka dilakukan pengelompokan. Pengelompokan tersebut dilakukan ke dalam 5 kategori: sangat tinggi, tinggi, sedang, rendah, sangat rendah

c. Statistik inferensial

Analisis statistik inferensial digunakan untuk menguji hipotesis penelitian dengan menggunakan uji-t dengan data berbeda. Namun sebelumnya dilakukan terlebih dahulu uji normalitas. Data penelitian ini dianalisis menggunakan program SPSS 16

1) Uji Normalitas Data

Kriteria pengujian normal bila $\chi 2$ hitung lebih kecil dari $\chi^{2}$ tabel di mana $\chi^{2}$ tabel diperoleh dari daftar $\chi^{2}$ dengan $d k=(\mathrm{k}-1)$ pada taraf signifikansi $\alpha=0,05$. Maka data tersebut berdistribusi normal. (Sarwoko 2008).

2) Uji Homogenitas

Nilai $F$ yang diperoleh dari perhitungan dikonsultasikan dengan $\mathrm{F}$ tabel yang mempunyai taraf signifikansi $=5 \%$. H0 diterima jika $\mathrm{F}$ hitung < F tabel dan $\mathrm{H0}$ ditolak jika F Hitung > F tabel(Sarjono and Julianita 2011).

3) Uji Hipotesis

Adapun cara untuk mengetahui ada tidaknya perbedaan pada hasil belajar Ekonomi pada kelas X di SMA Negeri 1 Liliriaja Kabupaten Soppeng yaitu dengan teknik statistik uji t. Pengujian hipotesis dimaksudkan untuk menjawab hipotesis yang telah diajukan.

\section{HASIL DAN PEMBAHASAN}

\section{Uji Instrumen Penelitian}

\section{a. Uji Validitas Soal}

Dalam penentuan layak atau tidaknya suatu item yang akan digunakan, biasanya dilakukan uji signifikansi koefisien korelasi pada taraf signifikansi 0,05 , artinya suatu item dianggap valid jika berkorelasi signifikan terhadap skor total. Jika $\mathrm{r}$ hitung $\geq \mathrm{r}$ tabel (uji 2 sisi dengan sig. 0,05), maka instrumen atau item-item soal berkorelasi signifikan terhadap skor total (dinyatakan valid).
Tabel 1.1 : Hasil Uji Validitas

\begin{tabular}{|l|l|l|l|}
\hline No & Rhitung & Rtabel & Ket \\
\hline 1 & 0,579 & 0,361 & Valid \\
\hline 2 & 0,696 & 0,361 & Valid \\
\hline 3 & 0,522 & 0,361 & Valid \\
\hline 4 & 0,770 & 0,361 & Valid \\
\hline 5 & 0,789 & 0,361 & Valid \\
\hline 6 & 0,541 & 0,361 & Valid \\
\hline 7 & 0,717 & 0,361 & Valid \\
\hline 8 & 0,648 & 0,361 & Valid \\
\hline
\end{tabular}

Berdasarkan hasil uji coba di atas terlihat bahwa semua item soal dinyatakan valid karena koefisien korelasinya $\geq 0,361$.

\section{b. Uji Reliabilitas Soal}

Menurut Sarjono (2011: 45), suatu kuesioner dikatakan reliabel jika memberikan nilai Cronbach Alpha > 0,60. Berdasarkan hasil uji coba reliabilitas instrumen dengan menggunakan bantuan SPSS diperoleh nilai Cronbach Alpha seperti yang terlihat pada Tabel 4.2 berikut.

Tabel 1.2 : Hasil Uji Reliabilitas

\begin{tabular}{|l|l|}
\hline Cronbach's Alpha & Keterangan \\
\hline .762 & Reliabel \\
\hline
\end{tabular}

Berdasarkan hasil uji reliabilitas di atas menunjukkan bahwa data tersebut reliabel karena memiliki nilai Cronbach Alpha $\geq 0.6$ sehingga dapat digunakan sebagai alat pengumpul data.

\section{Deskripsi Hasil Belajar}

\section{a. Deskripsi Rata-Rata Hasil Belajar Kelas Inkuiri Terbimbing di SMAN 1 Liliriaja Kabupaten Soppeng}

Tabel 1.3 : Rata-Rata Pre-Test Hasil Belajar Kelas Inkuiri Terbimbing

\begin{tabular}{|l|l|l|l|}
\hline Nilai & $\mathrm{Fi}$ & $\mathrm{Xi}$ & fi.xi \\
\hline $30-37$ & 4 & 31.25 & 125 \\
\hline $38-45$ & 4 & 41.25 & 165 \\
\hline $46-53$ & 3 & 50.00 & 150 \\
\hline
\end{tabular}




\begin{tabular}{|l|l|l|l|}
\hline $54-61$ & 6 & 55.83 & 335 \\
\hline $62-69$ & 3 & 65.00 & 195 \\
\hline $70-77$ & 10 & 72.50 & 725 \\
\hline Jumlah & 30 & & 1695 \\
\hline \multicolumn{2}{|l|}{ Rata-Rata Pre-Test } & $\mathbf{5 6 . 5 0}$ \\
\hline
\end{tabular}

Tabel 1.4: Rata-Rata Post-Test Hasil Belajar Kelas Inkuiri Terbimbing

\begin{tabular}{|c|c|c|c|}
\hline Nilai & $\mathrm{Fi}$ & $\mathrm{Xi}$ & fi.xi \\
\hline $65-68$ & 6 & 67.00 & 402 \\
\hline $69-72$ & 5 & 70.20 & 351 \\
\hline $73-76$ & 3 & 74.30 & 223 \\
\hline $77-80$ & 8 & 80.00 & 640 \\
\hline $81-84$ & 2 & 83.00 & 166 \\
\hline $85-88$ & 6 & 85.00 & 510 \\
\hline Jumlah & 30 & & 2292 \\
\hline \multicolumn{3}{|c|}{ Rata-Rata Post-Test } & 76,40 \\
\hline
\end{tabular}

Tabel 1.5: Nilai Statistik Deskriptif Hasil PreTest dan Post-Test Kelas Inkuiri Terbimbing

\begin{tabular}{|l|l|l|}
\hline \multirow{2}{*}{ Statistik } & \multicolumn{2}{|l|}{ Nilai Statistik } \\
\cline { 2 - 3 } & Pre-Test & $\begin{array}{l}\text { Post- } \\
\text { Test }\end{array}$ \\
\hline Nilai Terendah & 30 & 65 \\
\hline Nilai Tertinggi & 75 & 85 \\
\hline Nilai Rata-Rata $(\bar{x})$ & $\mathbf{5 6 . 5 0}$ & $\mathbf{7 6 . 4 0}$ \\
\hline
\end{tabular}

Berdasarkan hasil pre-test dan post-test pada kelas inkuiri terbimbing diperoleh nilai rata-rata hasil belajar Mata Pelajaran Ekonomi meningkat secara signifikan setelah dilakukan perlakuan, yakni nilai rata-rata pre-test adalah 52,83, sedangkan nilai rata-rata post-test adalah 76,40. dengan selisih sebanyak 19,90.

\section{b. Deskripsi Rata-Rata Hasil Belajar Kelas Inkuiri Bebas di SMAN 1 Liliriaja Kabupaten Soppeng}

Tabel 1.6 : Rata-Rata Pre-Test Hasil Belajar Kelas Inkuiri Bebas

\begin{tabular}{|c|c|c|c|}
\hline Nilai & $\mathrm{Fi}$ & $\mathrm{Xi}$ & fi.xi \\
\hline $30-37$ & 3 & 31.67 & 95 \\
\hline $38-45$ & 5 & 41.00 & 205 \\
\hline $46-53$ & 3 & 50.00 & 150 \\
\hline $54-61$ & 6 & 56.67 & 340 \\
\hline $62-69$ & 4 & 65.00 & 260 \\
\hline $70-77$ & 9 & 72.78 & 655 \\
\hline Jumlah & 30 & & 1705 \\
\hline \multicolumn{3}{|c|}{ Rata-Rata Pre Test } & 56.83 \\
\hline
\end{tabular}

Tabel 1.7 : Rata-Rata Post-Test Hasil Belajar Kelas Inkuiri Bebas

\begin{tabular}{|c|c|c|c|}
\hline Nilai & $\overline{F i}$ & $\mathrm{Xi}$ & fi.xi \\
\hline \multirow[t]{2}{*}{$48-52$} & & 49.00 & \\
\hline & 4 & & 196 \\
\hline $53-57$ & 11 & 54.90 & 604 \\
\hline $58-62$ & 7 & 59.43 & 416 \\
\hline $63-67$ & 4 & 64.00 & 256 \\
\hline $68-72$ & 2 & 68.00 & 136 \\
\hline $73-77$ & 2 & 75.00 & 150 \\
\hline Jumlah & 30 & & 1758 \\
\hline \multicolumn{3}{|c|}{ Rata-Rata Post Test } & 58.60 \\
\hline
\end{tabular}

Tabel 1.8: Nilai Statistik Deskriptif Hasil PreTest dan Post-Test Kelas Inkuiri Bebas

\begin{tabular}{|l|l|l|}
\hline \multirow{2}{*}{ Statistik } & \multicolumn{2}{|l|}{ Nilai Statistik } \\
\cline { 2 - 3 } & Pre-Test & $\begin{array}{l}\text { Post- } \\
\text { Test }\end{array}$ \\
\hline Nilai Terendah & 30 & 48 \\
\hline Nilai Tertinggi & 75 & 75 \\
\hline Nilai rata-rata $(\bar{x})$ & $\mathbf{5 6 , 8 3}$ & $\mathbf{5 8 , 6 0}$ \\
\hline
\end{tabular}

\section{c. Perbandingan Hasil Belajar Mata Pelajaran Ekonomi Menggunakan Metode Inkuiri Terbimbing dengan Inkuiri Bebas}

Berdasarkan perhitungan sebelumnya diketahui bahwa rata-rata hasil belajar Mata Pelajaran Ekonomi pada kelas Inkuiri Terbimbing adalah 56,50 untuk pre-test dan 76,40 untuk post-test. Sedangkan rata-rata hasil belajar Mata Pelajaran Ekonomi pada kelas Inkuiri Bebas adalah 56,83 untuk pre-test dan 58,60 untuk post-test. Adapun perbandingan hasil pre-test dan post-test untuk masing-masing model inkuiri terbimbing dan inkuiri bebas dapat dilihat pada gambar dibawah ini

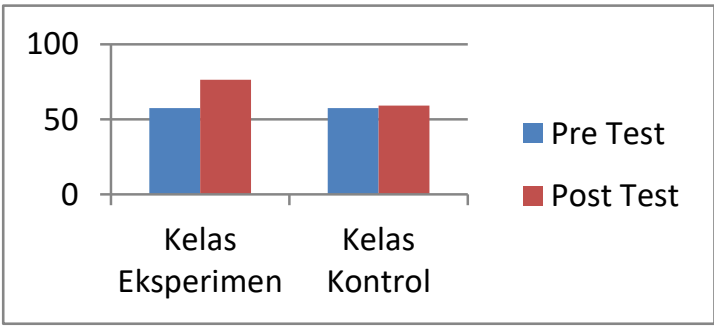


Gambar 1.1 Perbandingan Rata-Rata Hasil Belajar Kelas Inkuiri Terbimbing dan Inkuri Bebas

Adapun selisih rata-rata kenaikan hasil belajar peserta didik untuk kelas inkuiri terbimbing dapat dilihat pada table dibawah ini.

Tabel 1.9 Nilai Rata-Rata pada Pre-test dan Post-test Kelas Inkuiri Terbimbing

\begin{tabular}{|l|l|l|l|l|}
\hline \multirow{2}{*}{ Statistik } & \multicolumn{2}{|l|}{$\begin{array}{l}\text { Nilai } \\
\text { Statistik }\end{array}$} & Selisih & $\begin{array}{l}\text { Persen } \\
\text { tase } \\
(\%)\end{array}$ \\
\cline { 2 - 5 } & $\begin{array}{l}\text { Pre- } \\
\text { test }\end{array}$ & $\begin{array}{l}\text { Post- } \\
\text { test }\end{array}$ & \\
\hline $\begin{array}{l}\text { Nilai } \\
\text { rata-rata } \\
(\bar{x})\end{array}$ & 56,50 & 76,40 & 19,90 & 35,22 \\
\hline
\end{tabular}

Adapun selisih rata-rata kenaikan hasil belajar peserta didik untuk kelas inkuiri terbimbing dapat dilihat pada table dibawah ini,
Tabel 1.10 Nilai Rata-Rata pada Pre-test dan Post-test Kelas Inkuiri Bebas

\begin{tabular}{|l|l|l|l|l|}
\hline \multirow{2}{*}{ Statistik } & \multicolumn{2}{|l|}{$\begin{array}{l}\text { Nilai } \\
\text { Statistik }\end{array}$} & Selisih & $\begin{array}{l}\text { Persen } \\
\text { tase } \\
(\boldsymbol{\%})\end{array}$ \\
\cline { 2 - 4 } & $\begin{array}{l}\text { Pre- } \\
\text { test }\end{array}$ & $\begin{array}{l}\text { Post- } \\
\text { test }\end{array}$ & & \\
\hline $\begin{array}{l}\text { Nilai } \\
\text { rata-rata } \\
(\bar{x})\end{array}$ & 56,83 & 58,60 & 1,77 & 3,11 \\
\hline
\end{tabular}

Berdasarkan kedua tabel tersebut, dapat disimpulkan bahwa persentase selisih rata-rata kenaikan hasil belajar peserta didik untuk kelas inkuiri terbimbing lebih tinggi daripada kelas inkuiri bebas, dengan selisih mencapai 35,22\% $3,11 \%=32,11 \%$.

\section{Analisis Data}

\section{a. Uji Normalitas Data}

Jika data tersebut berdistribusi normal maka sig $>\alpha$ dan jika data tersebut tidak berdistribusi normal maka sig $<\alpha$. Pengujian normalitas yang dilakukan pada data kelas terbimbing dan kelas kontrol, ditetapkan taraf signifikannya adalah 0,05 .

Tabel 1.11 : Hasil Normalitas Data

\begin{tabular}{|l|l|l|l|l|l|}
\hline \multicolumn{2}{|c|}{} & XA_PreTest & XA_PostTest & XB_PreTest & XB_PostTest \\
\hline $\mathrm{N}$ & 30 & 30 & 30 & 30 \\
\hline \multirow{2}{*}{$\begin{array}{l}\text { Normal } \\
\text { Parameters }\end{array}$}
\end{tabular}

\section{b. Uji Homogenitas}

Pengujian homogenitas dilakukan pada data hasil pre-test dan post test, baik pada kelas inkuiri terbimbing maupun inkuiri bebas, dengan taraf signifikansi yang ditetapkan sebelumnya adalah $\alpha=0,05$. Jika sig $>\alpha$ maka $\mathrm{H}_{0}$ diterima, maka kedua data yang di uji homogen dan jika sig $<\alpha$ maka $\mathrm{H}_{0}$ ditolak, maka kedua data yang di uji tidak homogen. Hasil pengujian homogenitas dapat dilihat pada output SPSS.

Tabel 1.12 Pengujian Homogenitas terhadap Data Hasil Pre-test

\section{Test of Homogeneity of Variances}




\begin{tabular}{|l|l|l|l|}
\hline Pre_Test & & & \\
\hline $\begin{array}{l}\text { Levene } \\
\text { Statistic }\end{array}$ & df1 & df2 & Sig. \\
\hline .050 & 1 & 58 & .824 \\
\hline
\end{tabular}

Tabel 1.13 Pengujian Homogenitas terhadap Data Hasil Post-test

\begin{tabular}{|l|l|l|l|}
\hline \multicolumn{4}{|l|}{ Test of Homogeneity of Variances } \\
\hline Post_Test & & & \\
\hline $\begin{array}{l}\text { Levene } \\
\text { Statistic }\end{array}$ & df1 & df2 & Sig. \\
\hline .940 & 1 & 58 & .336 \\
\hline
\end{tabular}

Berdasarkan tabel di atas, maka diperoleh nilai sig sebesar 0,824 pada data hasil pre test, berarti nilai sig lebih besar dari nilai $\alpha=0,05(0,824>$ 0,05). Dengan demikian $\mathrm{H}_{0}$ di terima. Begitupula nilai sig sebesar 0,336 pada data hasil post test, berarti nilai sig lebih besar dari nilai $\alpha=0,05(0,336>0,05)$. Dengan demikian $\mathrm{H}_{0}$ di terima. Maka dapat disimpulkan bahwa data hasil pre-test dan post test pada kelas inkuiri terbimbing dan inkuiri bebas bersifat homogen.

\section{c. Uji Hipotesis}

Pengujian hipotesis yang digunakan dalam penelitian ini yaitu uji t-test dengan sampel independent. Kriteria pengujian hipotesis adalah Ho ditolak jika sig (2-tailed $<0,05)$, sedangkan Ho diterima jika sig (2-tailed $>0,05)$.

Tabel 1.14 : Hasil Uji Independent Sample T-Test

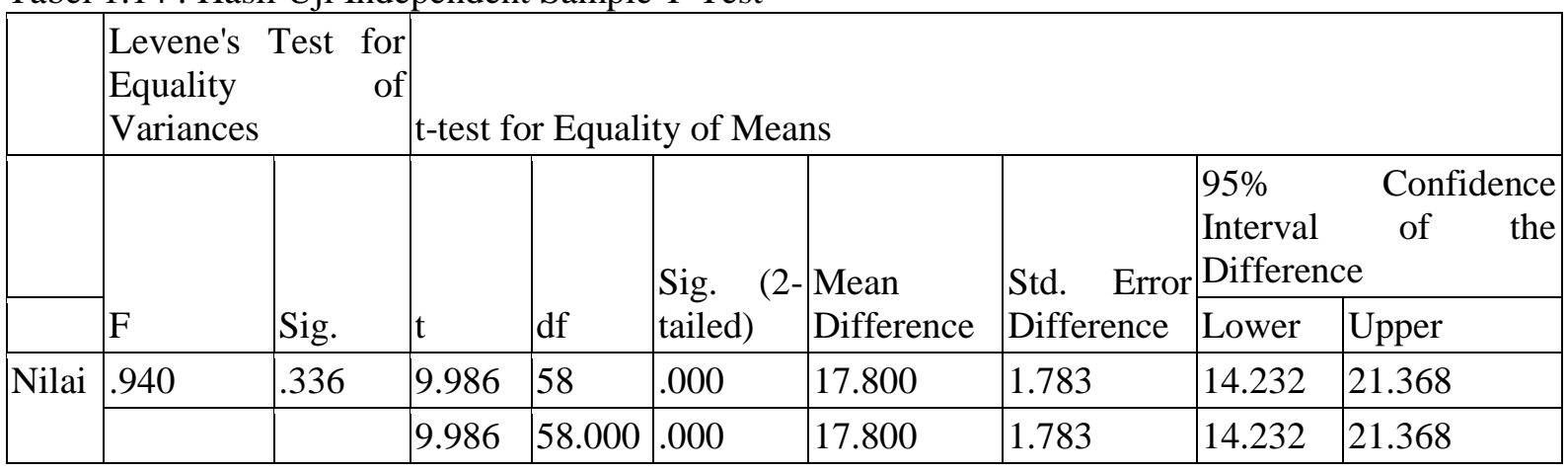

Berdasarkan pengujian hipotesis dengan menggunakan uji independent sample t-test, maka diperoleh nilai sig (2-tailed) sebesar 0,00 $<0,05$, sehingga dapat disimpulkan bahwa Ho ditolak dan Ha diterima, yang artinya terdapat perbedaan hasil belajar dalam penerapan model pembelajaran inkuri terbimbing dan inkuri bebas.

\section{SIMPULAN DAN SARAN}

Berdasarkan landasan teori dan didukung oleh analisis data hasil uji instrumen penelitian, maka dapat di simpulkan bahwa pengujian hipotesis dengan menggunakan uji independent sample ttest, maka diperoleh nilai sig (2-tailed) sebesar $0,00<0,05$, sehingga adapat disimpulkan bahwa terdapat perbedaan hasil belajar dalam penerapan model pembelajaran inkuri terbimbing dan inkuri bebas. Selain itu, dari hasil belajar yang diperoleh antara inkuri terbimbing dan inkuiri bebas, maka inkuri terbimbing lebih signifikan mempengaruhi peningkatan hasil belajar siswa di SMA Negeri 1 Liliriaja Kabupaten Soppeng.

\section{DAFTAR RUJUKAN}

Arikunto, Suharsimi. Prosedur Penelitian Suatu Pendekatan Praktik. Jakarta: Rineka Cipta, 2013.

Creswell, John W. Research Design Qualitative, Quantitative and Mixed Methods Approachs. Amerika: Sage Publications, 2014.

Dimyati, and Mudjiono. Belajar dan Pembelajaran. Jakarta: Rineka Cipta, 2013. 
Musdalifah, Sulfaidah. Perbandingan Hasil Belajar Siswa Kelas X Mata Pelajaran Ekonomi Menggunakan Model Inkuiri Terbimbing Dengan Ingkuiri Bebas di SMA Negeri 1 Liliriaja

Ristanto. Pembelajaran Berbasis Inkuiri Terbimbing dengan Multtimedia dan Lingkungan Riil Ditinjau dari Motivasi Berprestasi dan Kemampuan Awal. Surakarta: Universitas Sebelas Maret, 2010.

Sarjono, and Julianita. SPSS vs LISREL. Sebuah Pengantar Aplikasi untuk Riset. Jakarta: Salemba Empat, 2011.

Sarwoko. Statistik Inferensial untuk Ekonomi dan Bisnis. Yogyakarta: Andi, 2008.

Slameto. Belajar dan Faktor-Faktor yang Mempengaruhinya. Jakarta: Rineka Cipta, 2010.

Sudjana, Nana. Penilaian Hasil Proses Belajar Mengajar . Bandung: Remaja Rosdakarya, 2009.

Sugiyono. Metode Penelitian Pendidikan (Pendekatan Kuantitatif, Kualitatif, dan $R$ \& $D$ ). Bandung: Alfabeta, 2015.

Trianto. Mendesain Model Pembelajaran Inovatif-Progresif. Jakarta: Kencana, 2010.

Trianto. Model-Model Pembelajaran Inovatif Berorientasi Konstruktivistik. Jakarta: Prestasi Pustaka, 2008. 